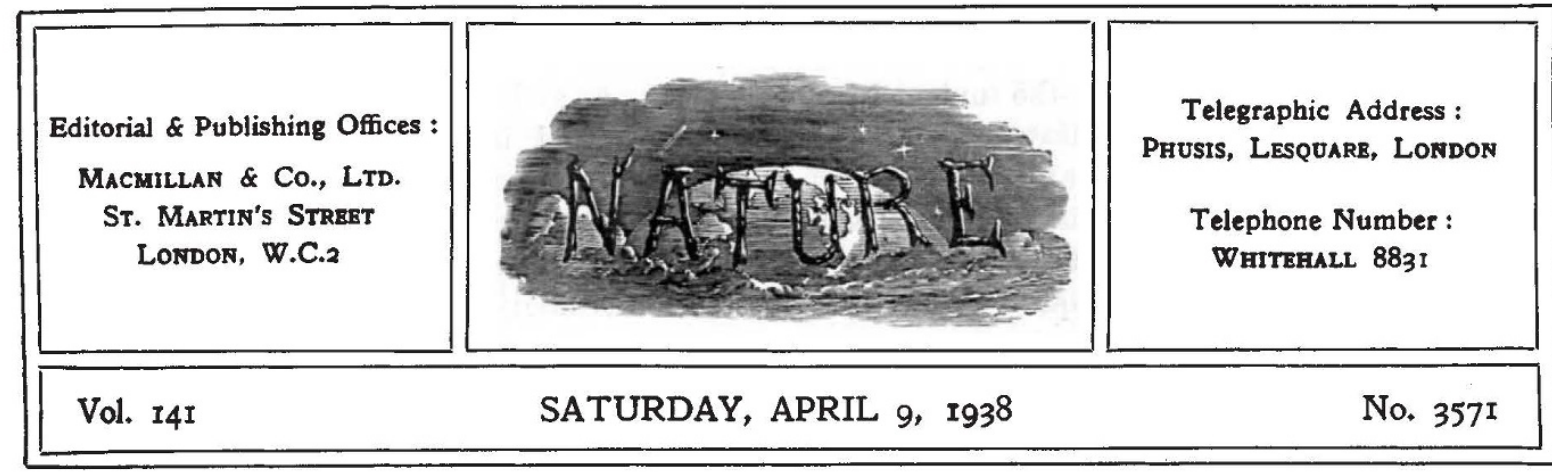

\title{
Blood and Soil
}

$\mathrm{T}^{\mathrm{H}}$ HE history of mankind is largely a story of the conflict of man's ideals, or, as the cynic would say, of his illusions. Of these the most potent, and in the long run the most enduring, are those affording the herd instinct fullest opportunity for play. This instinct, binding individuals by a bond of brotherhood in communities armed at all points for attack and defence, is at once selfregarding and altruistic. Appealing to both sides of human nature, in the struggle for existence it is the most effective of all the means of survival.

Among manifestations of the herd instinct the concept of 'race' has played a greater part in the development of modern civilization than any other factor, except perhaps religion. It is capable of wide extension ; and on occasion it over-rides the closest and most intimate ties, even, paradoxically enough, those of the family, from which it takes its origin. For the apotheosis of 'race', which is the very heart of the aggressive nationalism of modern Europe, derives the strength of its appeal, not so much from tribal origins, as from the blood-call which goes back to the intimate association of the primitive individual family and its blood-relationship. It is this tie which by a process of enlargement provides the binding force and the emotional colour in the progression of social organization from family to kin, tribe, people and nation ; and when transferred from the group to the territory it occupies, is capable of inspiring the noblest self-sacrifice and deeds of the loftiest patriotism. Cultural association and religious tradition undoubtedly play their part; but the ever-recurrent theme is the blood-tie.

Recent events in Central Europe have demonstrated how the racial idea could add dynamic force to a political movement for which neither historic tradition nor economic advantage had inspired adequate enthusiasm. In his speech before the Reichstag on March 18, Herr Hitler, reviewing the course of events of the preceding week, described the incorporation of Austria in the German Reich as "a racial triumph", and the culmination of a movement of "national-thinking people-to set up in place of a lying democratic violation of a people, the more holy rights of the eternal racial life". The sanctity of the racial life is to be further impressed on the population by the extension forthwith of German racial legislation to Austria.

To those who hold to the ideal of individual liberty and freedom of thought as the fundamental principle in intellectual and social progress, though they may admit the dynamic force inspired by a thoroughgoing acceptance of the racial idea, the intolerance, arrogance and injustice apparently inseparable from the discriminations of racial doctrine, when harnessed to political action, are wholly repugnant. What could be more significant as an example of the repression of individual judgment and the arrogant assumption of a right to eliminate the free expression of opinion, than Dr. Goebbels' own words, commenting on the statement that criticism was not allowed in Germany. They had no objection to criticism, he said, but it must be criticism from the superior to the inferior (The Times, March 23).

Germany does not stand alone. Wherever in social contacts discrimination has been imposed on the basis of racial groupings or the colour linepurely physical distinctions, be it said-these distinctions are made, unjustifiably, an imputation of innate inferiority, both intellectual and moral, in the excluded race or group. So it is said by a member of a people so highly race conscious as 
the Japanese, "From the fact of the divine descent of the Japanese people proceeds their immeasurable superiority to the natives of other countries"; thus the scholar Hirata, while the learned publicist, Dr. Uesugi Shinkichi, holds "it is now most clear that the salvation of the entire human race is the mission of our Empire".

Aryan doctrine perhaps has not yet gone so far as this except by implication, though its upholders maintain that all progress in civilization has been the work of the Aryans, of whom the German people as Nordics are the characteristic modern representatives. No student of European prehistory and ethnology, outside Germany, could endorse this claim. It is not known either that the Aryan-speaking peoples were racially homogeneous, all conforming to the Nordic type, nor would it be accepted as probable that a nomad pastoral people, such as the Nordics on their first appearance on the scene, were pioneers of a higher culture, when they impinged, for example, on the Minoan civilization of the Mediterranean, or the 'Dravidians' of India.

The discussion of innate racial superiority and inferiority in mental character is bootless. Too little is as yet known of racial psychology to justify a correlation of mental and physical characters, which would warrant the imputation of mental and moral superiority or inferiority in certain types of physical make-up. Even difference in cultural level-the state of backwardness-has yet to be shown to be a sign of inferiority in innate intellectual calibre. Investigation, so far as it has gone, affords no sufficient ground for the conclusion that 'primitive' peoples are intellectually stunted, even though their mental processes are environmentally conditioned; and it would be difficult to accept any assumption of inferiority where the members of the two racially contrasted groups have grown up and lived in an identical cultural environment, as have most of the Jews who have been expelled or excommunicated of late years in Central Europe. Even if, however, it were possible to correlate certain types of mental character with racial characters, the doctrine, if carried to its logical conclusion, demands purity of racial type, which, indeed, German policy would now seem to regard it as its aim to make coterminous with 'nation'. But most anthropologists hold the 'pure' race a fiction, while 'the racial type' in this context can only be regarded as an ideal, towards which peoples are continually evolving. This is apparently the view of Sir Arthur
Keith, when he maintains that a race is a nation in the making. Even in Germany, however, though the extent of the broad-headed element has been consistently minimized, the existence of mixed types has always been admitted; while even recently it has been advanced that a blonde pigmentation is not an essential criterion of Aryan descent. In fact, in the theory of a pure Aryan race, of which the Germans are the descendants, Nazi doctrine appears to have slipped into the familiar fallacy of translating the ideal at which it aims into a pseudo-historical fact of the past.

To be of any scientific value, 'race' as an entity must be susceptible of exact definition; but anthropologists are by no means agreed as to the criteria and precise value of the term. That there are such differences in physical character and appearance between individuals as to afford a strong presumption of ancestry and origin, and, therefore, in that partial sense racial, is a matter which, as Sir Arthur Keith is fond of pointing out, can be verified by anyone who walks down the street. If, however, an attempt is made to analyse the basis of this judgment more often than not it will be found to depend to a large extent upon colour, primarily of the skin, then of hair, and then eyes. An entertaining and instructive exercise is to imagine a white skin on some of our darker fellow-subjects encountered in street and train. It is surprising to find how often even an African might in feature pass for European, if the lips are not too thick. Yet there may be nothing to suggest European admixture. At the same time the Mongolian fold over the eye usually betrays the eastern Asiatic; yet occasionally it is found with other Mongolian facial characters in Europeans, both normal and abnormal.

On one fact anthropologists are agreed. Modern man belongs to one species, Homo sapiens, and that in this species are many varieties, or races, but that none of these can now be regarded as 'pure'. For purposes of classification and analysis, these varieties are grouped in terms of type, according to physical characters recorded by measurement and descriptive observation; but these racial types are abstractions for methodolog. ical convenience. When this type classification is applied to observation in the field, it is found that any given group no more than tends to conform to type within a certain range of variation. In effect, man is the most variable of all animals. The most that can be said of the races of man is that within the range of his variation at certain 
points certain physical characters show a tendency to become dominant, forming a nucleus, which for purposes of convenience is regarded as a racial type.

It by no means follows that this type is either universal within its area, or confined to it. In Europe, for example, Nordic, Alpine, Mediterranean may be the dominant types within the regions from which they take their respective names, but they are inextricably intermingled in varying proportions throughout the whole continent. Nordics and Alpines appear in Mediterranean lands, dark and broad-headed among the longheaded, blonde Scandinavians. For from the dawn of eivilization, Europe has been swept from end to end by racial migrations and invasions, which have left their legacy in an inheritance of fused racial characters, while in modern times facilities of transport and a freedom of intercourse in international relations have further tended to confuse the geographical distribution of physical type and racial distinction. In these conditions the racial type becomes a theoretical postulate and purity of race a claim without counterpart in fact. Nor do these conditions prevail in Europe alone. Ever since time began, man's wanderings and his conquests have tended to obliterate distinctions which isolation, inbreeding and tribal prejudice promoted and preserved, until only broad distinctions remain valid.

Acceptance of the strict biological view of race and the inheritance of physical characters in man does not preclude recognition of the patent fact that there are differences, some of them considerable, between the national and other local groupings of man which afford ostensible support for nationalist doctrine ; but they are due to environmental conditions rather than a physical inheritance. If, moreover, in physical character modern man is specifically one, it is no unfair assumption, unless due cause is shown to think otherwise, that in mental character man is also one, and that underlying cultural differences, which can be shown to be due to environmental and historical causes, there is a psychic unity, which can at need transcend nationalist and other separatist influences. In science, for example, man speaks a universal language and joins in a world-wide activity.

It is evident that in the development of the social organism from the primitive horde or individual family to the nation, the differences between local and other groupings have been subordinated to such elements as they have in common, in order that other groups, ever increasing in size and complexity, may be formed, in which, when once internal harmony has been established, the good of the whole may be pursued. Out of such groupings for a common end the modern civilized nations have arisen; and there is no inherent reason, so far as scientific studies of the growth of societies would go to show, why development should come to an end at the point which it has now reached. There have been, in fact, in recent years two experiments in carrying development further. Of these one is the British Communwealth of Nations, which has still to be submitted to a crucial test, the other the League of Nations, which, apart from its more widely advertised political action, has done a great work in science, economics and social reform for the advancement of the interests of mankind at large. In these fields of its activity, racial and national differences have proved no bar to co-operation, even though the time is not yet ripe for the joint political action which it was hoped that the League would promote. It is to some such larger unity that the scientific analysis of the history of human associations would appear to point as the goal of the future, rather than to an antagonism of rival national or racial entities, engaged in a struggle which belongs more properly to a pre-social stage of development.

In its origins science is one form of the response to man's eternal quest for law and order in the universe ; but from the earliest times it has also served his material needs. When primitive man first observed the ordered movement of the stars, it was not so much in satisfaction of a divine curiosity, as from the desire to arrive at some such law of seasonal progression as would enable him so to order his life as to ensure the proper care of flocks and herds and the sowing and harvesting of his crops; and so in the world of modern civilization. Knowledge may be pursued for its own sake, but it is no less the function of science to share in that planning for the future, which the development of social and economic organization makes more and more imperative every day. If, however, the study of man, his kinds and varied modes of life is to contribute to the solution of our problems, as it is only reasonable to anticipate, it must be as a study based on impartial and objective observation of fact, and not the forcing of fact to fit a biased and distorted political dogma born of fear and hatred-a science travestied in masquerade. 